\title{
The Indigent Defendant's Right to Court- Appointed Counsel in Civil Contempt Proceedings for Nonpayment of Child Support
}

When divorced fathers fall behind in court-ordered child support payments, courts may summon them to show cause why they should not be held in contempt. When no cause is found, the disposition is often a term in jail. ${ }^{1}$ Generally, the contempt is civil rather than criminal. ${ }^{2}$ Because confinement is intended only to co-

${ }^{1}$ For a detailed study of methods of enforcing child support, including the use of jail, in Michigan, see D. Chambers, Making Fathers Pay (1979). For data on the child support problem nationwide, see generally Staff of Senate Comm. on Finance, 94th Cong., 1st Sess., Child Support Data and Materials (Comm. Print 1975); J. Cassetty, Child Support and Public Policy (1978).

2 Many states have statutes that modify or supplement the common law of civil contempt as applied to nonpayment of support. E.g., ALASKa Stat. $\$ 11.35 .010$ (1962); Mich. Comp. LAwS ANN. §§ 552.201-.203 (West 1967). Criminal contempt charges may also be brought against fathers in arrears. E.g., Borden v. Borden, 67 Mich. App. 45, 48-49, 239 N.W.2d 757, 759 (1976); N.C. GeN. STat. § 50-13.4(f)(9) (Supp. 1981). Except to the extent that the statutes supplementing common law contempt may in effect make nonsupport contempt proceedings criminal in nature, see infra notes 38-44 and accompanying text, civil cuntempt for nonpayment of support is the exclusive subject of this comment.

In Gompers v. Bucks Stove \& Range Co., 221 U.S. 418 (1911), the Supreme Court reviewed standard doctrine distinguishing civil from criminal contempt:

[W] hether the proceedings be civil or criminal, there must be an allegation that in contempt of court the defendant has disobeyed [a court] order, and a prayer that he be attached and punished therefor. It is not the fact of punishment but rather its character and purpose that often serve to distinguish between the two classes of cases. If it is for civil contempt the punishment is remedial, and for the benefit of the complainant. But if it is for criminal contempt the sentence is punitive, to vindicate the authority of the court. ... [I]mprisonment for civil contempt is ordered where the defendant has refused to do an affirmative act required by the provisions of an order . . . mandatory in its character. Imprisonment in such cases is not inflicted as a punishment, but is intended to be remedial by coercing the defendant to do what he had refused to do. The decree in such cases is that the defendant stand committed unless and until he performs the affirmative act required by the court's order.

Id. at 441-42. See generally Penfield Co. v. SEC, 330 U.S. 585, 590 (1947); Gompers, 221 U.S. at 441-45; 67A C.J.S. Parent and Child \$ 87 (1978).

It would be misleading to pretend that the distinction between civil arid criminal contempt is clear and unproblematic. See Bessette v. W.B. Conkey Co., 194 U.S. 324, 328-29 (1904). Courts often conduct contempt proceedings and frame orders in ways that make it difficult to tell whether the proceeding is civil or criminal, thus providing a frequent issue in appeals. See, e.g., Shillitani v. United States, 384 U.S. 364, 368-70 (1966). For a history of the development of the law of civil and criminal contempt, see generally R. GoldFarB, THE 
erce performance and not to punish an offense, ${ }^{3}$ the father's ability to comply is a prerequisite to confinement for civil contempt. The father must have the opportunity to purge his contempt at any time by complying with the court order; ${ }^{5}$ compliance brings immediate release. ${ }^{\circ}$

Civil contempt proceedings for nonpayment of child support are typically informal hearings in which many of the due process safeguards of criminal trials are not available to the defendant.? Often he is not allowed to call witnesses or to cross-examine adverse witnesses. ${ }^{8} \mathrm{~A}$ jury trial is almost never granted..$^{\circ}$ Some courts allow the defendant to hire his own lawyer, ${ }^{10}$ but the court seldom appoints a lawyer for him if he is indigent and unable to afford one. ${ }^{11}$

The supreme courts of Alaska, ${ }^{12}$ Washington, ${ }^{13}$ and Iowa ${ }^{14}$ and one federal district court ${ }^{15}$ have held, however, that indigent defen-

Contempt Powgr 49-67 (1963); Beale, Contempt of Court, Criminal and Civil, 21 Harv. L. REv. 161 (1908).

E.g., Johansen v. State, 491 P.2d 759, 766 (Alaska 1971).

4 See, e.g., Maggio v. Zeitz, 333 U.S. 56, 76 (1948); Ex parte Sanders, 608 S.W.2d 343

(Tex. Civ. App. 1980).

s E.g., Johansen, 491 P.2d at 764.

- See Gompers, 221 U.S. at 442.

'See, e.g., Johansen, 491 P.2d at 765; Sword v. Sword, 399 Mich. 367, 387, 249 N.W.2d 88, 96 (1976). See generally Comment, The Coercive Function of Civil Contempt, 33 U. CHI. L. REV. 120, 120 (1965).

- See generally D. Chambers, supra note 1, at 174-76.

- See, e.g., Sword, 399 Mich. at 384-86, 249 N.W.2d at 94-95. But see Johansen, 491 P.2d at 762.

${ }^{10}$ See generally Annot., 52 A.L.R.3D 1002 (1973).

1 See D. Chambers, supra note 1 , at 174.

12 Otton v. Zaborac, 525 P.2d 537 (Alaska 1974).

$1 s$ Tetro v. Tetro, 86 Wash. 2d 252, 544 P.2d 17 (1975).

14 McNabb v. Osmundson, 315 N.W.2d 9 (Iowa 1982). When the Iowa Supreme Court held that these indigent defendants have a right per se to counsel, it treated the proceedings as involving criminal contempt. Id. See generally infra notes 40-42 and accompanying text.

${ }_{15}$ Mastin v. Fellerhoff, 526 F. Supp. 969 (S.D. Ohio 1981); Young v. Whitworth, 522 F. Supp. 759 (S.D. Ohio 1981). The Supreme Court of Ohio, however, has said that there is no right to counsel in these proceedings under the sixth amendment. In re Calhoun, 47 Ohio St. $2 d$ 15, 16-17, 350 N.E.2d 665, 666-67 (1976) (per curiam) (dictum). One federal court of appeals has said that there is a right per se to counsel. Henkel v. Bradshaw, 483 F.2d 1386, 1390 (9th Cir. 1973) (dictum). A Wisconsin intermediate court has held that an indigent defendant is entitled to court-appointed counsel in a civil contempt action initiated by the district attorney. Brotzman v. Brotzman, 91 Wis. $2 d$ 335, 339-40, 283 N.W.2d 600, 601-02 (Ct. App. 1979) (nonsupport contempt proceeding; decided on the basis of state statute). A Pennsylvania superior court has held that a nonsupport defendant in civil contempt proceedings has a due process right to assistance of counsel. Commonwealth ex rel. Brown v. Hendrick, $220 \mathrm{~Pa}$. Super. 225, 283 A.2d 722 (1971).

Four United States circuit courts of appeals have held that defendants in civil contempt proceedings involving refusal to testify or to produce documents have a right to appointed 
dants in these proceedings have a right to appointed counsel. The supreme courts of Michigan, ${ }^{16}$ New Hampshire, ${ }^{17}$ New Mexico, ${ }^{18}$ and North Carolina ${ }^{18}$ have held that there is no automatic right to counsel but that courts should appoint counsel in individual cases where due process requires it. This comment examines the question, not yet resolved by the Supreme Court, whether an indigent defendant faced with jail in civil contempt proceedings for nonpayment of child support has a right to appointed counsel. The comment looks to both the sixth amendment's guarantee of the assistance of counsel and the fourteenth amendment's due process clause as independent sources of a right to counsel. The comment concludes that the sixth amendment is inapplicable except in the few states where the nonsupport contempt proceedings may be characterized as criminal prosecutions. But even when the sixth amendment is not applicable, due process requires the appointment of counsel for an indigent defendant before he may be jailed for contempt.

\section{The Sixth Amendment Approach}

The sixth amendment provides that "[i]n all criminal prosecutions the accused shall enjoy the right ... to have the Assistance of Counsel for his defence." ${ }^{20}$ In Gideon $v$. Wainwright ${ }^{21}$ the Su-

counsel. United States v. Anderson, 553 F.2d 1154, 1156 (8th Cir. 1977) (refusal to produce records); In re Di Bella, 518 F.2d 955, 959 (2d Cir. 1975) (refusal to answer grand jury questions while under grant of immunity); In re Kilgo, 484 F.2d 1215, 1221 (4th Cir. 1973) (refusal to answer questions before grand jury while under grant of immunity); United States v. Sun Kung Kang, 468 F.2d 1368, 1369 (9th Cir. 1972) (refusal to answer grand jury questions). In two of these cases, the courts held broadly that the Constitution requires that counsel be appointed for indigent persons in any type of civil contempt proceeding where the defendant is faced with the prospect of imprisonment, Anderson, $553 \mathrm{~F} .2 \mathrm{~d}$ at 1156; $\mathrm{Di}$ Bella, 518 F.2d at 959, which presumably could include cases of nonsupport contempt.

10 Sword v. Sword, 399 Mich. 367, 383, 249 N.W.2d 88, 94 (1976).

17 Duval v. Duval, 114 N.H. 422, 426-27, 322 A.2d 1, 4 (1974).

18 State ex rel. Department of Human Servs. v. Rael, 97 N.M. 640, 642 P.2d 1099, 1103 04 (1982).

10 Jolly v. Wright, 300 N.C. $83,93-94,265$ S.E.2d 135, 143 (1980).

20 U.S. CoNsT. amend. VI.

21372 U.S. 335 (1963). Gideon expressly overruled Betts v. Brady, 316 U.S. 455, 461-62 (1942), where the Court refused to extend the sixth amendment guarantee of counsel to the states and interpreted the due process clause of the fourteenth amendment as requiring appointment of counsel only when want of counsel could result in a conviction lacking in fundamental fairness. Gideon, 372 U.S. at 339. In overruling Betts, the Court relied on the broad language of its earlier decision in Powell v. Alabama, 287 U.S. 45 (1932), stating that Betts "departed from the sound wisdom upon which the Court's holding in Powell v. Alabama rested." Gideon, 372 U.S. at 345 . Powell held that the due process clause of the fourteenth amendment requires a state trial court to assign counsel to any defendant in a capital 
preme Court held that the sixth amendment, made applicable to the states by the due process clause of the fourteenth amendment, ${ }^{22}$ requires that a lawyer be provided to indigent defendants in state felony trials. ${ }^{23}$ In Argersinger v. Hamlin ${ }^{24}$ the Court extended the Gideon result, holding that "absent a knowing and intelligent waiver, no person may be imprisoned for any offense, whether classified as petty, misdemeanor, or felony, unless he was represented by counsel at his trial."25

Some courts have found Argersinger applicable to imprisonment for civil contempt. They hold that the Court intended to make imprisonment the determinant of the right to counsel,

case who is unable to employ counsel and is incapable of adequately making his own defense "because of ignorance, feeble mindedness, illiteracy, or the like." Powell, 287 U.S. at 71.

22 U.S. Const. amend. XIV, § 1.

${ }^{23}$ In Gideon the Court overruled Betts, see supra note 21, but did not clearly state what rule it was adopting. Expansive language in the opinion strongly suggested that the Court was guaranteeing the right to representation for indigents in any criminal proceeding: "Not only these precedents but also reason and reflection require us to recognize that in our adversary system of criminal justice, any person haled into court, who is too poor to hire a lawyer, cannot be assured a fair trial unless counsel is provided for him." Gideon, 372 U.S. at 344. But Justice Harlan in a concurring opinion stated that the holding was more limited:

The special circumstances rule has been formally abandoned in capital cases, and the time has now come when it should be similarly abandoned in noncapital cases, at least as to offenses which, as the one involved here, carry the possibility of a substantial prison sentence. (Whether the rule should extend to all criminal cases need not now be decided.)

Id. at 351 (Harlan, J., concurring) (emphasis in original). In later opinions, e.g., In re Gault, 387 U.S. 1, 29 (1967), the Court assumed that the holding of Gideon had not yet been extended to misdemeanor cases. See also Argersinger v. Hamlin, 407 U.S. 25, 44 n.1 (1972) (Powell, J., concurring in result).

24407 U.S. 25 (1972).

${ }^{23}$ Id. at 37 . Argersinger was sometimes read to grant a right to representation by counsel whenever a defendant is charged with any criminal offense for which the law prescribes confinement as a possible disposition. E.g., Potts v. Estelle, 529 F.2d 450, 454 (5th Cir. 1976). The Court made it clear in Scott v. Illinois, 440 U.S. 367 (1979), that this reading was an unwarranted expansion of the Argersinger holding. Argersinger, according to Scott, held only that a defendant may not be imprisoned if he was not represented by counsel. Id. at 373-74. Thus if a defendant is tried without counsel for a misdemeanor or a petty offense for which the law prescribes a fine or a jail term, but he is only fined, he has no complaint under Argersinger. (If he is charged with a felony, Gideon applies. See supra notes 21-23.)

Argersinger requires a court to appoint counsel only if the misdemeanor or petty offense with which the defendant is charged carries a mandatory term of confinement. When confinement is optional, a court need appoint counsel only when it wishes to preserve that sentencing option.

Both the Gideon rule and the Argersinger rule allow the defendant to appear without counsel if he knowingly and intelligently waives his right. This proviso will be treated as understood throughout the following discussion whenever those or other rules relating to the right to counsel are mentioned. For the requirements of a "knowing and intelligent waiver," see Von Moltke v. Gillies, 332 U.S. 708, 723-24 (1948). 
whether the proceeding is criminal or civil. ${ }^{26}$ It is doubtful that the Court intended to go that far. ${ }^{27}$ Although the Argersinger holding refers to "any offense," the succeeding clause-"whether classified as petty, misdemeanor, or felony"-gives standard categories of criminal offenses, strongly suggesting that the holding is limited to them. More fundamentally, the Court was construing the sixth amendment, which is limited in express words to "criminal prosecutions." ${ }^{28}$ Argersinger is controlling, therefore, only if civil contempt proceedings are criminal prosecutions under the sixth amendment.

Under traditional common law doctrine, contempt proceedings are "sui generis-neither civil actions nor prosecutions for offenses, within the ordinary meaning of those terms."28 Consistently with that doctrine, the Supreme Court has several times declared that criminal contempt proceedings are not criminal prosecutions in the sixth amendment sense. ${ }^{30}$ In Bloom v. Illinois, ${ }^{31}$ however; the Court held that criminal contempt is a crime in every fundamental respect, to which the jury trial provisions of article $\mathrm{III}^{32}$ and the sixth amendment apply. Following its interpretation of those provisions in Duncan v. Louisiana, ${ }^{33}$ the Court ruled that petty contempts, like other petty crimes, can be tried without a jury, but serious criminal contempts have to be tried with a jury if the defendant so insists. ${ }^{34}$ Although the Court did not explicitly overturn the principle that criminal contempts are not criminal prosecutions

${ }^{28}$ See, e.g., Henkel v. Bradshaw, 483 F.2d 1386, 1390 (9th Cir. 1973) (dictum); Tetro v. Tetro, 86 Wash. 2d 252, 253-55, 544 P.2d 17, 19 (1975).

${ }_{27}$ See, e.g., Sword v. Sword, 399 Mich. 367, 380-81, 249 N.W.2d 88, 93 (1976); Duval v. Duval, 114 N.H. 422, 424-26, 322 A.2d 1, 3 (1974); Jolly v. Wright, 300 N.C. 83, 90-91, 265 S.E.2d 135, 141 (1980).

${ }^{23}$ U.S. ConsT. amend. VI.

${ }^{29}$ Myers v. United States, 264 U.S. 95, 103 (1924).

so E.g., Levine v. United States, 362 U.S. 610, 616 (1960); Green v. United States, 356 U.S. 165, 186 (1958); Myers v. United States, 264 U.S. 95, 104-05 (1924). The Court nevertheless has long recognized that proceedings for criminal contempt not committed in open court must include certain due process safeguards if requested: notice of charges, an opportunity to defend, the right to call witnesses, and the assistance of retained counsel. Cooke v. United States, 267 U.S. 517, 537 (1925). See also Bloom v. Illinois, 391 U.S. 194, 195-99 (1968) (reviewing earlier case law). One court has found the Argersinger right to counsel applicable in such cases. See In re Grand Jury Proceedings, 658 F.2d 211, 217 n.10 (3d Cir. 1981).

31391 U.S. 194 (1968).

32 U.S. ConsT. art III, § 2, para. 3.

33391 U.S. 145 (1968).

st Bloom, 391 U.S. at 210; see Codispoti v. Pennsylvania, 418 U.S. 506, 511 (1974). The Court later held that no offense for which imprisonment of more than six months is authorized can be deemed "petty." Baldwin v. New York, 399 U.S. 66, 69 (1970). 
in the sixth amendment sense, it must have done so implicitly, for if not, the sixth amendment could not have been a basis for the holding.

If the Court now recognizes criminal contempt proceedings as criminal prosecutions under the sixth amendment, then the right to appointed counsel recognized in Gideon $v$. Wainwright and Argersinger $v$. Hamlin must belong as well to indigent defendants charged with criminal contempt. When the punishment faced by the defendant is comparable to that for felonies, the court must always appoint counsel; if the court fails to appoint counsel in lesser cases, it may not imprison the defendant.

But even if criminal contempt proceedings are criminal prosecutions in the sixth amendment sense, it by no means follows that civil contempt proceedings are. Several Supreme Court cases make it clear that a proceeding is not made a criminal prosecution simply by the fact that it may result in the imprisonment of the defendant. $^{35}$ The proceeding must have other elements traditionally associated with a criminal trial, such as punitive sentencing and public prosecution. ${ }^{36}$ But common law civil contempt is coercive, not punitive. Although the proceedings are adversarial in the sense that there is a plaintiff and a defendant, the plaintiff is a private party and not a professional prosecuting attorney. Proceedings are instituted by the complaint of the private party aggrieved, not by indictment or information. ${ }^{37}$ In such cases, where the principal similarity to criminal proceedings is the possibility that a prison sentence may result, the sixth amendment is not implicated.

Some states, however, have modified the common law of civil

ss E.g., Middendorf v. Henry, 425 U.S. 25, 35 (1976) (summary court martial not a criminal prosecution, though imprisonment may result); Gagnon v. Scarpelli, 411 U.S. 778, 782 (1973) (probation revocation hearing not a stage in a criminal prosecution).

s6 Middendorf, 425 U.S. at 35 . The Court denied that summary courts martial are criminal trials requiring appointment of counsel under the sixth amendment because much of the conduct prohibited by the Uniform Code of Military Justice and tried in summary courts martial is not "criminal" in the civilian sense of the word, the penalties authorized are narrowly limited, the trial itself is not an adversary proceeding with a prosecuting attorney, id. at 38-42, and the proceeding takes place "in the military community with all of its distinctive qualities," $i d$. at 42. In Kennedy v. Mendoza-Martinez, 372 U.S. 144 (1963), however, the Court found that persons faced with loss of American citizenship for draft evasion are entitled to a criminal trial with all the incidents of due process under the fifth and sixth amendments, including the assistance of counsel. Id. at 167. The holding is based solely on the finding that Congress intended the sanction of loss of citizenship to be punishment. Id. at 165-66. Although the Court does not explicitly make the point, the holding seems to imply that any proceeding in which the defendant faces punitive sanctions is a criminal prosecution.

s7 See generally Gompers v. Bucks Stove \& Range Co., 221 U.S. 418, 444-45 (1911). 
contempt as applied to nonpayment of child support. In some states, for example, the contempt action is brought by the public prosecutor, who presents the state's case in court. ${ }^{38}$ In other states, the county department of public services or the like prosecutes the case, acting as the mother's agent or as the assignee of the mother's support claim. ${ }^{39}$ Such modifications create a resemblance to criminal cases, because there is public prosecution of a public wrong with the potential for a punitive outcome: the state marshals its forces to bring charges, gather and produce evidence, and argue for a contempt citation; there is an ostensible public wrong to be vindicated, for nonpayment of support involves the violation of a court order and imposes on society the burden of support; and the defendant may be sentenced to jail. The potential for punitive rather than coercive sanctions may be seen in Iowa, where a statute allows the courts to sentence to jail for up to thirty days anyone who wilfully disobeys a support order. ${ }^{40}$ Such a sentence, if imposed without a purge condition and without a showing of present ability to pay support, can only be punitive, ${ }^{41}$ and indeed the statute itself speaks of punishing for contempt. ${ }^{42}$ That proceedings modified in those ways may still be called "civil" cannot dispose of their status for constitutional purposes. ${ }^{43}$ At least in those cases

${ }^{38}$ See, e.g., Chase v. Chase, 287 Md. 472, 475, 413 A.2d 208, 210 (1980) (state's attorney, representing wife, filed contempt petition).

so See, e.g., Jolly v. Wright, 300 N.C. 83, 83, 265 S.E.2d 135, 137 (1980). See generally McClelland \& Eby, Child Support Enforcement: The New Mexico Experience, 9 N.M.L. REv. 25, 36 (1978-1979) (state sues in own name as assignee of welfare recipient's rights and as real party in interest; welfare recipient usually does not participate in suit).

so If any party against whom any temporary order or final decree has been extended shall willfully disobey the same, or secrete his property, he may be cited and punished by the court for contempt and be committed to the county jail for a period of time not to exceed thirty days for each offense.

Iowa CODE § 598.23 (1975). Such punishment may be imposed even if the amounts in default are paid before the contempt hearing. Id. \$ 598.22. The Iowa Supreme Court has declared the quoted provision to be primarily punitive, particularly when viewed in the light of § 598.22. McNabb v. Osmundson, 315 N.W.2d 9, 15 (Iowa 1982).

${ }^{4}$ See supra notes 3-6 and accompanying text.

42 IOWA CODE § 598.23 (1975), quoted supra note 40.

4s Thus in In re Gault, 387 U.S. 1 (1967), the Court rejected the argument that the constitutional privilege against self-incrimination does not apply to juvenile proceedings because they are civil:

[J]uvenile proceedings to determine "delinquency," which may lead to commitment to a state institution, must be regarded as "criminal" for purposes of the privilege against self-incrimination. To hold otherwise would be to disregard substance because of the feeble enticement of the "civil" label-of-convenience which has been attached to juvenile proceedings . . . F For this purpose, at least, commitment is a deprivation of liberty. It is incarceration against one's will, whether it is called "criminal" or "civil."

Id. at 49-50. Cf. Boyd v. United States, 116 U.S. 616, 634 (1886) ("[P]roceedings instituted 
where the criminal law elements of public prosecution, public harms, and punitive sentencing predominate, these statutes ought to be treated as having transformed the proceedings into criminal prosecutions to which the sixth amendment applies. ${ }^{44}$

Contempt proceedings for nonpayment of support can thus be divided into three classes. At one extreme is criminal contempt, to which the sixth amendment is surely applicable. At the other extreme is common law civil contempt, which is not governed by the sixth amendment, even when imprisonment results. In between is an array of statutes that modify civil contempt. When contempt proceedings under such statutes are criminal in substance, the sixth amendment applies, and the court must provide counsel for indigent defendants if it wishes to preserve the option of imprisonment. ${ }^{46}$ In the majority of cases that are not appropriately considered criminal, however, any right to counsel that might exist must be found elsewhere.

\section{The Fourteenth Amendment Approach}

The sixth amendment is not the only possible source of a right to counsel. Even when the Supreme Court has found proceedings not to be criminal prosecutions and therefore not subject to the sixth amendment's requirements, the Court nevertheless has found that the fourteenth amendment's due process clause sometimes supports a right to appointed counsel. ${ }^{47}$ When the Court has found

for the purpose of declaring the forfeiture of a man's property by reason of offenses committed by him, though they may be civil in form [and so denominated by statute], are in their nature criminal" and subject to the fourth and fifth amendments.). See generally Tetro v. Tetro, 86 Wash. 2d 252, 254-55, 544 P.2d 17, 19 (1975) (civil contempt proceedings are quasi-criminal in nature; defendants are complained against by the county prosecutor, required to appear and defend against charges of past illegal conduct, and, most important, face the possibility of imprisonment if their defenses fail); Ex parte Davis, 161 Tex. 561, 564, 344 S.W.2d 153, 155-56 (1961) (civil contempt hearing has some incidents of a trial for crime and is quasi-criminal in nature).

14 Cf. Bloom v. Illinois, 391 U.S. 194, 201 (1968) ("Criminal contempt is a crime in the ordinary sense; it is a violation of the law, a public wrong which is punishable by fine or imprisonment or both. . . . [C]onvictions for criminal contempt are indistinguishable from ordinary criminal convictions, for their impact on the individual defendant is the same.").

${ }^{4}$ Some states expressly authorize criminal contempt proceedings for nonpayment of child support. E.g., N.C. GEN. Stat. § 50-13.4(f)(9) (Supp. 1981) (disobedience of "[a]n order for the payment of child support ... may be punished by proceedings for criminal contempt"). Criminal contempt, however, requires wilful disobedience of the support order, id. §5A-11(a)(3) (1981), which imports knowledge and a stubborn resistance, Mauney v. Mauney, 268 N.C. 254, 257, 150 S.E.2d 391, 393 (1966).

18 See supra notes 21-25 and accompanying text.

17 E.g., Lassiter v. Department of Social Servs., 452 U.S. 18 (1981); Gagnon v. Scarpelli, 411 U.S. 778 (1973); In re Gault, 387 U.S. 1 (1967). 
such a right, ${ }^{48}$ it has followed one of two paths. Either it has found a per se right to counsel for all indigent defendants in proceedings of a certain character, ${ }^{49}$ or it has left it to case-by-case evaluations by particular administrative or judicial bodies to determine whether to appoint counsel for indigent litigants appearing before them. ${ }^{80}$

The leading case for contemporary due process analysis in right-to-counsel cases ${ }^{81}$ as elsewhere is Mathews $v$. Eldridge. ${ }^{.2}$ In that case the Court gave its clearest general statement of the analysis to be performed in deciding what process is due. One must consider

first the private interest that will be affected by the official action; second, the risk of an erroneous deprivation of such interest through the procedures used, and the probable value, if any, of additional or substitute procedural safeguards; and finally, the government's interest, including the function involved and the fiscal and administrative burdens that the additional or substitute procedural requisites would entail. ${ }^{.3}$

The private interest referred to is the liberty or property interest that implicates the due process clause. The formula tells us, in effect, to weigh the reduction of the risk of error against the net additional fiscal and administrative burdens a new procedure would impose, in light of the importance of the interest threatened with loss. It is a form of cost-benefit analysis, providing a framework for determining whether the benefit of the due process right under consideration is worth its cost. Although the use of such a test may be preferable to exclusive reliance on intuitions of fair-

18 For numerous proceedings, the Court has concluded that due process does not require the appointment of counsel. E.g., Goldberg v. Kelly, 397 U.S. 254, 270 (1970) (pretermination hearing for public assistance payments).

10 See In re Gault, 387 U.S. 1, 41 (1967) (juvenile delinquency determinations).

${ }^{\text {so }}$ See Lassiter v. Department of Social Servs., 452 U.S. 18, 31-32 (1981) (termination of parental rights); Gagnon v. Scarpelli, 411 U.S. 778, 790 (1973) (probation revocation).

sx Lassiter, 452 U.S. at 27 (opinion of the Court), 37 (Blackmun, J., joined by Brennan and Marshall, JJ., dissenting). Although one might think that analogy to prior right-tocounsel cases is the preferred method of analysis, analogy is an inappropriate starting point because due process is such a flexible concept. The Court has repeatedly emphasized that what process is due in a given type of case depends on the balance of the constellation of competing public and private interests involved. See Goldberg v. Kelly, 397 U.S. 254, 263 (1970). Since no two types of cases will have the same competing interests in the same proportions, the balancing must be done anew each time a due process issue arises.

82424 U.S. 319 (1976).

ss Id. at 335 . 
ness, ${ }^{54}$ its utility should not be overemphasized. Determining the costs and benefits and comparing their value remain matters for estimation and judgment rather than precise computation, and different persons may estimate and judge differently. ${ }^{55}$ Even when aided by the Eldridge test, due process analysis has an unavoidably subjective aspect. The Eldridge formula for deciding what process is due under the fourteenth amendment nevertheless can be applied usefully in most cases.

This part applies the Eldridge analysis to nonsupport contempt proceedings, considering first the nature of the liberty interest at stake, then the potential reduction in risk of error to be gained from the appointment of counsel, and finally the net increase in the burden on the state. In the end, however, it is necessary to return to earlier right-to-counsel decisions to see how the Eldridge balance should be struck.

\section{A. The Eldridge Analysis}

1. The Interest at Stake. The interest at stake is the defendant's physical liberty-his freedom from confinement by the state. ${ }^{56}$ It does not require citation to establish the preeminent importance our society and our judicial system accord to physical liberty. The only question is whether the defendant's interest is in some way reduced in civil contempt proceedings. ${ }^{.7}$

It is sometimes said that confinement for civil contempt is not

s4 This may concede too much. The basic axiom of due process is that government proceedings in which protected interests of individuals are in jeopardy must be fundamentally fair. See, e.g., Lassiter, 452 U.S. at 24 . Whether fundamental fairness is adequately explicated by a cost-benefit analysis remains to be shown. There are reasons for deep disquietude. Can the government always defeat a claim to a due process right merely by showing that it costs too much? Does an inefficient government owe less to the governed in the way of due process than an efficient one? Despite these concerns over the philosophical basis for the Eldridge test, it will be accepted in this comment as determinative of due process rights.

ss For a thorough and penetrating critique of the Eldridge test, see Mashaw, The Supreme Court's Due Process Calculus for Administrative Adjudication in Mathews v. Eldridge: Three Factors in Search of a Theory of Value, 44 U. CHr. L. Rev. 28 (1976) (failing of Eldridge is its focus on questions of technique rather than on questions of value).

se It must be borne in mind that "interest" in this context is roughly synonymous with "right." The defendant's interest in his liberty is his right to remain free, not his desire to be free or the interest he takes in his own freedom. One's interest in physical liberty can be contrasted with one's rights in the care and custody of one's child, which also have been deemed a "liberty" interest. Lassiter v. Department of Social Servs., 452 U.S. at 38 (Blackmun, J., dissenting), 59 (Stevens, J., dissenting).

${ }^{87} \mathrm{~A}$ liberty interest exists in discounted form when, for example, one is on probation under a suspended sentence of imprisonment. In such a case, one's right to physical freedom is subject to termination if one violates the conditions of probation. See Gagnon v. Scarpelli, 411 U.S. 778, 781-82 (1973). 
like confinement for crime, that the civil contemnor can secure his release at any time simply by complying with the order of the court, and that his liberty interest is therefore not as great as that of a criminal defendant. ${ }^{58}$ As the old saw has it, he carries the keys to his prison in his pocket. ${ }^{59}$ There are at least two objections to this argument. First, those who are unlawfully confined, because no purge condition is $\operatorname{set}^{60}$ or because conditions are set that they are unable to meet, ${ }^{61}$ cannot secure their release at any time; for them the old saw is simply false. Second, even where confinement is lawful, the defendant's liberty interest is not altered by his ability to secure his own release any more than it is when a defendant faces a five-year rather than a ten-year prison sentence; the magnitude of the threat to liberty does not change the underlying liberty interest itself. Similarly, the defendant's liberty interest is not reduced because confinement for civil contempt is coercive rather than punitive. The purpose of the confinement is irrelevant to the strength of the antecedent right not to be confined. ${ }^{62}$

If the nonsupport contempt defendant has a diminished interest in his freedom, it can only be as a result of some earlier judicial proceeding and not of the disposition he faces in the present one. ${ }^{63}$ But the typical nonsupport defendant has been ordered only to make child support payments. This court-imposed obligation may put practical constraints on his freedom of action-he may have to

${ }^{88}$ In State ex rel. Department of Human Servs. v. Rael, 97 N.M. 640, 642 P.2d 1099 (1982), the court argued as follows:

Here, the defendant's interest in his personal liberty, though an extremely important one, is not as strong as it would be if he were being criminally prosecuted or charged with criminal contempt. He will lose his liberty only if it is proven that he has the ability to comply and fails to make arrangements to do so.

Id., 642 P.2d at 1102.

Bo E.g., In re Nevitt, 117 F. 448, 461 (8th Cir. 1902); Duval v. Duval, 114 N.H. 422, 425, 322 A.2d 1,3 (1974). As old saws go, this is one of the worst. It conveys the misleading idea that confinement for civil contempt is somehow voluntary or self-inflicted, not really confinement at all. It draws attention away from the fact that the state puts contemnors in jail and keeps them there. To gain release, they must comply with conditions dictated by the state. In every important sense the key stays firmly in state hands. Confinement for civil contempt is no less an application of the power of the state against the individual than confinement for a like term for crime. See generally D. Chambers, supra note 1, at 187; $R$. GoldfarB, supra note 2, at 59-61; Comment, supra note 7, at 125.

so See infra note 80 and accompanying text.

B1 See infra notes 82-84 and accompanying text.

${ }^{62}$ Cf. In re Gault, 387 U.S. 1 (1967) (Court found right to appointed counsel even though purpose of sanction was rehabilitation of juvenile offender rather than punishment).

es Cf. Gagnon v. Scarpelli, 411 U.S. 778, 789 n.12 (1973) (contrasting due process rights of probationers and parolees with those of juveniles charged with delinquency; juvenile "entitled to a higher degree of protection" than "an already-convicted probationer or parolee"). 
give up some leisure activities because of his need to earn money. Such constraints, however, are not themselves court-imposed and do not diminish his right to remain free of confinement. ${ }^{64}$ It is true that the court order exposes the father to coercive measures if he refuses or neglects to comply, but since confinement is only one of many possible coercive measures, since any coercion requires a proper judgment of contempt, and since the choice of measures is left to the discretion of the judge with confinement as a last resort, a father's susceptibility to coercive confinement is at most only a slight contingent encumbrance on his freedom. ${ }^{65}$

2. The Risk of Error and the Value of an Attorney. To understand the risks of error in nonsupport contempt proceedings, it is necessary to review the basic premises of the proceedings. A defendant can be held in civil contempt only if he has not complied with the court order to pay support and he has the ability to comply. Inability to comply is a complete defense. ${ }^{68}$ Proof of ability to comply requires a showing that the defendant has the resources to meet the court-ordered payments, allowing a reasonable amount for his own subsistence. ${ }^{67}$ If he has the means to comply, the court is justified in reordering his priorities by applying coercive measures. $^{68} \mathrm{~A}$ court exceeds its powers, however, if it confines a man on

s4 Indeed, physical liberty generally is a necessary condition for the defendant to comply with the court order. Confinement removes him from his job and the income out of which he might satisfy his support obligation. Confinement may cause him to lose his job, so that when he is released he is less able to pay than before. See Marston v. Oliver, 324 F. Supp. 691,696 (E.D. Va. 1971) ("Any incarceration of over thirty days, more or less, will usually result in loss of employment, with a consequent substantial detriment to the defendant and his family."), rev'd on other grounds, 485 F.2d 705 (4th Cir. 1973), cert. denied, 417 U.S. 936 (1974). If he is unemployed before being confined, his jail record and the possibility of future confinement may make it more difficult for him to find employment when he is released.

ss Contrast the position of one serving a criminal sentence who is released for work during weekdays but must return to jail at night and remain there on weekends. Such a person has a sharply reduced interest in freedom for the duration of his confinement.

6s See Maggio v. Zeitz, 333 U.S. 56, 72 (1948): "Of course, to jail one for a contempt for omitting an act he is powerless to perform would reverse this principle [that civil contempt proceedings are coercive] and make the proceeding purely punitive, to describe it charitably." See also Shillitani v. United States, 384 U.S. 364, 371 (1966) (where grand jury has been finally discharged, "a contumacious witness can no longer be confined, since he then has no further opportunity to purge himself of contempt").

${ }^{07}$ E.g., N.H. REv. STAT. ANN. \& 546-A:2 (1974) ("Every person whose income or other resources are more than sufficient to provide for his or her reasonable subsistence compatible with decency or health owes a duty to support or contribute to the support of his or her . . . child . . . when in need."). See also Haynes v. Haynes, $168 \mathrm{Kan} .219,226,212$ P.2d 312, 317-18 (1949) (affirming trial court holding that nonsupport defendant was not guilty of contempt on grounds that he could not both support himself and make the payments).

os State constitutional and statutory guarantees against imprisonment for debt do not 
the ground either that he is healthy and able to work ${ }^{69}$ or that he could prevail upon relatives to pay the sum required for his release. ${ }^{70}$ Similarly, a court cannot jail the defendant in order to punish him. ${ }^{71}$ Finally, confinement should be the coercive measure of last resort. If other means short of confinement will produce compliance with the support order, they should be employed. ${ }^{22}$

The possible erroneous decisions a court may make number at least four: (1) wrongly determining that the defendant has not complied with the court order; (2) wrongly deciding that coercive measures are required to obtain compliance; (3) jailing when other means of forcing payment are available; (4) sentencing punitively, either without a purge condition, for too long a term, or with a purge condition that the defendant cannot meet or one that the court is not permitted to impose. ${ }^{73}$

The risk of jailing a man who is satisfying his support obliga-

apply to liabilities based on orders or decrees for the support of minor children made in independent civil proceedings. See, e.g., Johnson v. Johnson, 241 Md. 416, 419, 216 A.2d 914, 916 (1966); Chase v. Griffin, 31 A.D.2d 681, 295 N.Y.S.2d 821 (1968). See generally D. CHAmbers, supra note 1, at 244-45; 16 C.J.S. Constitutional Law § 204(2) (1956) and cases cited therein.

69 See, e.g., Commonwealth ex rel. Brown v. Hendrick, 220 Pa. Super. 225, 283 A.2d 722 (1971) (defendant's physical appearance, showing no physical infirmity or disability precluding gainful employment, not enough to establish that his failure to comply with order to support wife and children was contemptuous or wilful); Sword v. Sword, 399 Mich. 367, 387. 88,249 N.W.2d 88, 96 (1976) (remand because trial judge had used failure to pay and present physical ability of the defendant to work as sole criteria for incarceration). Cf. Johansen v. State, 491 P.2d 759, 768 (Alaska 1971) (trial court was wrong to order fisherman to leave lifelong home and seek employment in a city or be found in contempt).

70 Andrews v. McMahan, 43 N.M. 87, 90-91, 85 P.2d 743, 745 (1938). The Supreme Court's statement in Maggio v. Zeitz, 333 U.S. 56 (1948), though referring to an order to return assets to a bankrupt company, could be applied equally well to jailing for nonpayment of support: "It should not be necessary to say that it would be a flagrant abuse of process to issue such an order to exert pressure on friends and relatives to ransom the accused party from being jailed." Id. at 64 .

71 E.g., Johansen v. State, 491 P.2d 759, 766 (Alaska 1971).

72 See infra notes 77-79 and accompanying text.

73 Throughout the following discussion it must be borne in mind that some states may authorize by statute some of the actions here identified as errors under the common law. Michigan, for example, authorizes the court to jail a nonsupport defendant for contempt if he "is of sufficient ability to comply with [the] order, or by the exercise of diligence could be of sufficient ability, and has neglected or refused to do so." Mrch. Comp. Laws ANN. § 552.201 (West 1967) (emphasis added). Where there are such statutory modifications, however, it must always be asked whether they effectively convert a civil contempt into a criminal contempt. See supra notes 38-46 and accompanying text. Under the Michigan statute, for example, a defendent can be jailed if the court finds that by the exercise of diligence he would be able to comply with the support order. Such a jailing, without a work release provision, can only be punitive. No authority has been found declaring whether jailing with a work release provision is legitimately coercive within the common law of civil contempt. 
tions is slight. ${ }^{74}$ Determining whether he is complying is a simple question of fact, easy to ascertain. ${ }^{75}$ In the event of noncompliance, however, the more difficult question is whether to impose coercive measures, and this depends upon whether he is able to comply. When the defendant is indigent, his very indigency increases the likelihood that he has neither the assets nor the income to satisfy the demands of the court. Thus determination of an indigent's ability to comply is especially delicate and susceptible to error. ${ }^{78}$

The remaining risks arise only after it has been determined that the defendant has the ability to meet his obligations but has not done so. In such cases, the court will have several means available to compel payment, and the risk is that it will incorrectly select confinement. If the defendant has assets, the court can order execution. ${ }^{77}$ If he has wages, the court can require a wage assignment or order garnishment. ${ }^{78}$ Confinement is appropriate only when the defendant is known to have the means to pay but has concealed his assets, refused to sign a wage assignment, or otherwise resisted reasonable efforts to obtain payment. ${ }^{79}$

74 Nevertheless, such cases exist. See, e.g., Nystrom v. District Court, 244 Iowa 735, 739, 58 N.W.2d 40, 42 (1953) (trial court had no right to sentence nonsupport defendant to jail for contempt when he had paid in full the amount due). Iowa law has since been amended to permit such a sentence. See supra note 40 .

${ }^{73}$ See, e.g., Sword v. Sword, 399 Mich. 367, 382, 249 N.W.2d 88, 93 (1976).

78 That a nonsupport defendant is indigent for the purpose of qualifying for appointed counsel does not mean, however, that he is indigent for all purposes or that ipso facto he cannot meet his child support payments. The test for indigency varies with the purpose of the determination. See Hardy v. United States, 375 U.S. 277, 289 n.7 (1964) (Goldberg, J., concurring). A person might have the means to meet modest child support payments without being able to retain private counsel to defend him in contempt proceedings. Indigency need not mean destitution. See United States v. Cohen, 419 F.2d 1124, 1127 (8th Cir. 1969). For an account of the factors to be considered in determining indigency for purposes of appointment of counsel, see Bramlett v. Peterson, 307 F. Supp. 1311, 1323 (M.D. Fla. 1969). See generally Annot., 51 A.L.R.3D 1108 (1973).

The effect of indigency on compliance makes civil contempt proceedings for the collection of support payments differ markedly from those intended to coerce other sorts of performance, such as testifying or delivering documents. Wealth is not essentially connected to ability to comply with these other sorts of court orders, and therefore it is no less likely a priori that an indigent defendant can perform.

${ }^{77}$ E.g., CaL. Civ. Code $\$ 4380$ (West Supp. 1982). See generally H. ClaRK, LaW of DOMBSTIC RELATIONS 509 (1968) (discussing use of writ of execution to enforce child support decree).

78 E.g., Mrch. Comp. LAws ANN. $\$ 552.203$ (West 1967) (authorizing involuntary wage assignments); N.C. GEN. STAT. § 50-13.4(f)(4) (Supp. 1981) (authorizing garnishment); Wis. STAT. ANN. § 767.265 (West Supp. 1982) (authorizing involuntary wage assignments). Although garnishment is limited by federal law in most cases, see 15 U.S.C. $\S 1673(a)$ (1976 \& Supp. V 1981), these limits do not apply to court orders "for the support of any person," id. $\S 1673(\mathrm{~b})$.

70 See Burton v. Wayne Circuit Judge, 325 Mich. 159, 165, 37 N.W.2d 899, 901-02 
If the court has correctly determined that confinement is appropriate, it may err in the terms of confinement it imposes, as by omitting a purge condition or by setting an excessive term in jail.80 The risk of punitive confinement, intentional or inadvertent, is considerable. The court's sense that failure to obey its past order offends the dignity of the court and the orderly administration of justice and the court's outrage over the defendant's dereliction of moral duty may create a strong impetus toward punitive sentencing. ${ }^{81}$ Even a dispassionate court may mistakenly believe that it is authorized to impose a jail sentence on a defendant without the means to pay, in order to motivate him to greater diligence in the future. Such a sentence is not coercion as that term is used in the context of civil contempt, since the defendant is unable to make the court-ordered payments. The proper term for it is deterrence: the court hopes to deter future noncompliance. The purpose is plainly punitive; deterrence is one of the classic aims of punishment.

(1949); Mason Furniture Corp. v. George, 116 N.H. 451, 453, 362 A.2d 188, 189-90 (1976). See gênerally Comment, supra note 7, at 128-30 (arguing that imprisonment when lesser remedies are available may be unconstitutional unless "criminal due process rights" are afforded the civil contemnor).

so Courts do sometimes fail to set a purge condition. E.g., Sword v. Sword, 399 Mich. $367,387-88,249$ N.W.2d 88, 96 (1976) (trial judge sentenced defendant to one year in jail with no provision for release upon purge of the contempt). Excessive confinement may be difficult to identify because there is no definite point at which a coercive confinement, because of its length, becomes punitive. For a clear example of excessive confinement, see Chase v. Chase, 287 Md. 472, 485, 413 A.2d 208, 215 (1980) (Eldridge, J., dissenting) (trial court sentenced nonsupport contemnor to six years' imprisonment although his uncontradicted testimony clearly established a prima facie case of inability to pay).

It is quite plausible that the longer a man is in jail without meeting the purge condition, the more likely it is that he does not know he can purge the contempt or that he is not able to, in which case his confinement is punitive. Justice Levin, concurring in Sword, recognized this problem and suggested that circuit courts "review the civil contempt jail population periodically, not later than two weeks after sentence, and reassess determinations that the defendant has the present ability to pay; if the defendant is indigent, counsel should then be assigned to represent him." 399 Mich. at 399, 249 N.W.2d at 101 (Levin, J., concurring). Cf. Maggio v. Zeitz, 333 U.S. 56, 76 (1948):

It is everywhere admitted that even if [a bankrupt] is committed [for civil contempt for failure to produce goods], he will not be held in jail forever if he does not comply. His denial of possession is given credit after demonstration that a period in prison does not produce the goods. The fact that he has been under the shadow of prison gates may be enough, coupled with his denial and the type of evidence mentioned above, to convince the court that his is not a wilful disobedience which will yield to coercion.

21 Contemptuous conduct . . . often strikes at the most vulnerable and human qualities of a judge's temperament. Even when the contempt is not a direct insult to the court or the judge, it frequently represents a rejection of judicial authority, or an interference with the judicial process or with the duties of officers of the court.

Bloom v. Illinois, 391 U.S. 194, 202 (1968). 
Finally, the court may err by setting a purge condition that the defendant cannot presently satisfy. ${ }^{82} \mathrm{~A}$ court may not require payment of a sum in settlement of arrearages unless the court knows that the contemnor either has the money or can raise it from his own assets. ${ }^{83}$ Nor is it proper to sentence the defendant to prison to work off his arrearages from prison earnings: the civil contempt power does not comprehend commitment to involuntary servitude. $^{\text {s4 }}$

It is apparent, therefore, that neither the contested issues nor the errors in nonsupport contempt proceedings are likely to involve basic facts-the terms of the support order, the failure to stay current, the amount of the arrearage. Rather, the case is likely to turn on the more difficult questions of the defendant's ability to comply and the minimal coercive measures needed to produce compliance. The errors at risk are likely to involve the coercive sanctions-incarcerating instead of garnishing wages, omitting a purge condition or setting one incapable of attainment, sentencing punitively, and the like. Undoubtedly many courts adhere scrupulously to the ground rules for civil contempt and handle cases with admirable sensitivity. But it is equally certain that there are courts that do not. ${ }^{85}$ The risk inheres in the use of civil contempt proceedings to secure money payments from people with very limited means. The question is how the presence of counsel would affect the likelihood of error.

The defendant already enjoys minimal due process protec-

22 Some states have statutes allowing confinement of nonsupport defendants in contempt proceedings, even if they are unable to pay. E.g., Iowa CoDE $\S \S 598.22-.23$ (1975). But such a confinement is clearly punitive. McNabb v. Osmundson, 315 N.W.2d 9, 14-15 (Iowa 1982). See supra note 40 and accompanying text.

ss See, e.g., Johnson v. Johnson, 241 Md. 416, 419, 216 A.2d 914, 917 (1966) (if father unable to meet support obligation because without sufficient estate or present ability to pay, court not justified in incarcerating him); cf. Commonwealth ex rel. Brown v. Hendrick, 220 Pa. Super. 225, 283 A.2d 722 (1971) (defendant held in civil contempt and ordered to pay $\$ 500$ on the support order for $\$ 42$ monthly or serve three months in house of correction).

* Such a disposition, however, may be authorized by statute. In Michigan, for example, a court may confine a father in default to a state prison for as long as he is in contempt, up to a year, and may order that all or part of his prison earnings be applied to the arrearage. Mrch. Comp. Laws ANN. $\$ 552.201$ (West 1967). This extreme measure arguably makes the contempt criminal, despite the possibility of purging. See supra notes $38-46$ and accompanying text.

ss For chilling examples see the account of the Chase and Bowman cases in the dissenting opinion in Chase v. Chase, $287 \mathrm{Md} .472$, 475-81, $413 \mathrm{A.2d} 208,210-13$ (1980) (Eldridge, J., dissenting) (appeals dismissed as moot). A more pedestrian example is Borden v. Borden, 67 Mich. App. 45, 50-51, 239 N.W.2d 757, 760 (1976) (defendant confined without adequate determination of sufficient ability to comply). See generally D. Chambers, supra note 1, at 174-89. 
tions. He generally has notice of the charges against him and in all cases is afforded a hearing. However, the defendant is often given no opportunity to call witnesses or to cross-examine adverse witnesses. ${ }^{86}$ But these rights would be of little value to the indigent defendant if not accompanied by the right to counsel. Indigent defendants typically are uninformed as to their rights, unaware of the limitations on the court's powers, unable to recognize judicial error, unskilled in effective speaking, and intimidated by the trappings of authority. ${ }^{87} \mathrm{~A}$ defendant who has no forensic skills or courtroom experience is not likely to benefit from the right to call witnesses, to have a more complete statement of the plaintiff's case before trial, or to cross-examine adverse witnesses. ${ }^{88}$ Moreover, when the defendant readily admits the principal issue-nonpayment of support-and is unaware that a range of coercive sanctions, not simply imprisonment, is available, it is unclear how even a defendant who has courtroom skills could adequately protect himself. $^{\mathbf{8 0}}$

The one additional right that might conceivably aid an indigent defendant, short of providing counsel, is providing him a brief, clear statement of the law of contempt and the limits on the court's power. With this information, some defendants might be able to prevent improper sanctions against themselves. But even here, without courtroom skills and without an advocate, the defendant is at a severe disadvantage. When the issue is ability to pay or the proper coercive measure, the answer will turn mainly on the credibility of the defendant himself. If the defendant has no ability to make support payments, the judge may have to be convinced that he cannot lawfully send him to jail. If the defendant has some ability to make payments, the judge must be made to believe that the defendant's resources are what he says they are, and he must be made to believe that the defendant will comply with whatever

se See supra notes 7-11 and accompanying text.

87 See generally D. Chambers, supra note 1, at 174-89.

ss But cf. Gagnon v. Scarpelli, 411 U.S. 778, 786 (1973) (finding that notice of charges and anticipated evidence and rights to testify, call witnesses, and cross-examine witnesses could in most cases adequately meet requirements of due process). See infra notes 113-39 and accompanying text (distinguishing Scarpelli). Another protection the defendant enjoys is the right of appeal, but this right is worthless to someone who cannot recognize reversible error, who is unfamiliar with the channels of appeal, and whose freedom of action is reduced by confinement in the county jail.

${ }^{80}$ Cf. Sword v. Sword, 399 Mich. 367, 397, 249 N.W.2d 88, 100 (1976) (Levin, J., concurring) ("An untrained person on the defensive in the unfamiliar environment of the courtroom may require assistance to respond adequately to the proofs adduced by the moving party's lawyer, the prosecuting attorney, friend of the court or the judge."). 
new payment terms might be agreed to. On these issues the judge quite reasonably may be skeptical: the defendant will often have admitted not paying support when he has had some ability to do so, and the fact that someone has brought him to court may suggest that previous efforts to settle have failed. Moreover, nonsupport defendants are not an appealing lot; haled into court for neglecting their parental duties and for defying a court order, they are hardly likely to arouse a judge's confidence or sympathy. ${ }^{90}$

With an advocate, the risk of error can be reduced substantially. The lawyer can assist accurate factfinding, prepare and present defenses, present credible witnesses and evidence, monitor the actions of the court, make timely objections and motions, and take immediate actions if the court wrongfully confines his client. ${ }^{91}$ In cases where the defendant is able to arrange some form of payment, there is evidence that a lawyer can be far more effective than

9o See generally D. Chambers, supra note 1, at 182-84. The Supreme Court has long recognized that it is unrealistic to depend on the judge to look after the defendant's interests:

One of the grounds upon which Lord Coke defended the rule [denying the aid of counsel to one accused of a felony] was that in felonies the court itself was counsel for the prisoner. But how can a judge, whose functions are purely judicial, effectively discharge the obligations of counsel for the accused? He can and should see to it that in the proceedings before the court the accused shall be dealt with justly and fairly. He cannot investigate the facts, advise and direct the defense, or participate in those necessary conferences between counsel and accused which sometimes partake of the inviolable character of the confessional.

Powell v. Alabama, 287 U.S. 45, 61 (1932) (citation omitted). In nonsupport contempt proceedings, moreover, the court may, in effect, be an adverse party, primarily concerned with enforcing its order and with the interests of the mother, the children, and the state in securing the required payments. See generally supra note 81 and accompanying text (discussing tendency of judges to see violations of court orders as directly insulting the judicial process).

- This is a point often made in discussions of the right to appointed counsel. It was made best by Justice Sutherland in Powell v. Alabama, 287 U.S. 45 (1932), in the context of a criminal proceeding. The substance of those remarks applies to civil contempt proceedings as well, with necessary changes in detail:

The right to be heard would be, in many cases, of little avail if it did not comprehend the right to be heard by counsel. Even the intelligent and educated layman has small and sometimes no skill in the science of law. If charged with crime, he is incapable, generally, of determining for himself whether the indictment is good or bad. He is unfamiliar with the rules of evidence. Left without the aid of counsel he may be put on trial without a proper charge, and convicted upon incompetent evidence, or evidence irrelevant to the issue or otherwise inadmissible. He lacks both the skill and knowledge adequately to prepare his defense, even though he may have a perfect one. He requires the guiding hand of counsel at every step in the proceedings against him. Without it, though he be not guilty, he faces the danger of conviction because he does not know how to establish his innocence.

Id. at 68-69. Cf. In re Gault, 387 U.S. 1, 36 (1967) (juvenile needs assistance of counsel to cope with problems of law, to make skilled inquiry into facts, to insist upon regularity of proceedings, and to ascertain whether he has a defense and to prepare and submit it). 
the defendant at presenting a plan and convincing the court to accept it.92 The lawyer is able to speak the language of the court, he can present a cogent and feasible payment scheme, and he can lend his credibility to the defendant's case..$^{93}$ In his roles as both negotiator and advocate, therefore, the lawyer can prevent the most serious error risked in contempt proceedings, unlawful confinement, and he can help formulate coercive measures short of confinement to ensure that the children's need for support is met.

3. The Fiscal and Administrative Burden. The costs of appointing counsel include the cost of paying attorneys, the cost of delays and court time if attorneys are used, and the cost of providing welfare payments to replace child support payments lost if appointment of counsel is required. ${ }^{94}$ These costs will vary with the number of attorneys appointed, and that number will vary according to the rule adopted.

Under the present regime, under which counsel is almost never appointed, the costs of appointment are negligible. Under a rule that leaves the question of the appointment of counsel to caseby-case determinations, the frequency of appointment is difficult to predict and will doubtless vary from place to place. In many courts there would be no noticeable difference between a case-bycase rule and the present regime-counsel would seldom be appointed, and defendants would continue to be jailed. If a Gideontype rule were imposed on all courts, the costs would be at their highest, since the court would have to appoint counsel whenever it summoned an indigent defendant in civil contempt proceedings. ${ }^{95}$ But if an Argersinger-type rule were adopted, the court would have to appoint counsel only when it wished to preserve the option of confining the defendant. ${ }^{96}$ Knowing that counsel would be present in such cases, and knowing that appointing counsel is costly to the state, courts would try to preserve the option of confinement

92 See D. Chambers, supra note 1, at 185-87.

93 See id. at 186.

- The Michigan Supreme Court, in finding no constitutional right to appointed counsel, was especially concerned about costs:

The magnitude of probably more than doubling the number of appointed counsel to be paid for in the main part by local funds is apparent. The exorbitant financial burden would be equalled by a need for more court time, personnel and space to accomodate [sic] defendants' demands for counsel and jury trial. Sword v. Sword, 399 Mich. 367, 382-83, 249 N.W.2d 88, 94 (1976).

${ }^{25}$ See generally Gideon v. Wainwright, 372 U.S. 335 (1963); supra notes 21-23 and accompanying text.

20 See generally Argersinger v. Hamlin, 407 U.S. 25 (1972); supra notes 24-25 and accompanying text. 
only in cases in which it seemed antecedently probable that confinement would be both lawful and effective. Thus an Argersingertype rule would give courts an incentive to use means other than confinement. The cost to the state would be much less than under a Gideon-type rule because counsel would be appointed less often.

Any calculation of costs must take into account the savings that a given rule will produce. Under the present regime, states that resort extensively to jailing pay heavily for maintaining the delinquent fathers in jail. ${ }^{97} \mathrm{~A}$ case-by-case rule would produce little reduction in that expense. But if one of the other two rules were adopted, the use of jailing would predictably diminish, since lawyers would check the improper use of jail and help work out arrangements that would make jail unnecessary.8 ${ }^{88}$ Because lawyers would not be appointed in all cases under an Argersinger-type rule, the net cost of this rule could compare quite favorably with the present regime, once savings are taken into account.

The calculation of costs must also proceed on the assumption that the government will make deliberate, good faith efforts to contain costs; otherwise the government could defeat a due process right by artificially making it too costly to administer. Under an Argersinger-type rule, screening cases carefully in advance to determine if there is reason to suppose that an indigent defendant is able to comply may be less costly than appointing counsel routinely. If so, the cost of prescreening with occasional appointment of counsel, and not the cost of appointing counsel in every case, should be reckoned into the due process calculation.

Finally, there is no reason why providing counsel to indigent defendants in appropriate cases must result in a reduction of support payments and an increase in the public's burden of support. If the defendant can pay, the court may confine him even though he is represented by counsel. If he cannot pay, then he will not pay, whether confined or not, and whether represented by counsel or not.

\section{B. Drawing the Balance}

The nonsupport defendant's interest in his liberty is essen-

${ }^{97}$ For example, the costs budgeted by one small Michigan county in 1974 were $\$ 10$ per prisoner per day. D. Chambers, supra note 1, at $101 \mathrm{n} .17$. In the same county in 1969-70, nearly 190 jail sentences were issued, $i d$. at 336 (Table 8A), and the average number of days served was 99, $i d$. at 337 (Table 8C). Assuming that prison costs per prisoner were the same in 1970 as in 1974, the county had to spend nearly $\$ 190,000$ to jail the men that year.

s8 See supra notes 91-93 and accompanying text. 
tially undiminished. ${ }^{99}$ The reduction in risk of error if appointment of counsel is required would be considerable. ${ }^{100}$ The costs to the state of appointing counsel would vary according to the caseload and the form of rule adopted; an Argersinger-type rule presents opportunities for containing the costs within reasonable bounds. ${ }^{101}$ The final step in the Eldridge analysis is to determine whether the reduction in risk of error is enough to justify the extra cost, considering the importance of the interest at stake. ${ }^{102}$ Although the Eldridge test takes us this far, it takes us no farther. Even if the values of the three critical variables have been estimated accurately, the test does not show how to determine whether the reduction in risk of error is enough.

A promising way to surmount this difficulty is to compare the results of the analysis here with the results the Supreme Court itself has obtained in previous cases in which the right to appointed counsel under the fourteenth amendment was in issue. In two of these cases ${ }^{103}$ the Court adopted a case-by-case rule; in the third, a per se rule. ${ }^{104}$ If the dispositon of Eldridge factors more closely resembles the latter case, as will be argued, then a per se rule is appropriate for nonsupport contempt.

The Court's most recent opinion addressing the right to counsel under the fourteenth amendment is Lassiter $v$. Department of Social Services. ${ }^{108}$ Lassiter is the only such case decided since $E l$ dridge and hence is the only one to apply Eldridge analysis. The petitioner in Lassiter claimed that she was improperly denied appointed counsel in state court proceedings that terminated her parental rights. The Court held that a parent's right to appointed counsel in such proceedings should be decided by the trial judge on a case-by-case basis and that there was no error in denying counsel in Lassiter's case. ${ }^{108}$

Before applying the Eldridge test, the Court established a presumption, based on a survey of its earlier cases, that there is no right to appointed counsel unless the person claiming the right

- Supra notes 56-65 and accompanying text.

${ }^{100}$ Supra notes 86-93 and accompanying text.

101 Supra notes 94-98 and accompanying text.

102 Supra notes 52-55 and accompanying text.

${ }^{103}$ Lassiter v. Department of Social Servs., 452 U.S. 18 (1981); Gagnon v. Scarpelli, 411 U.S. 778 (1973).

104 In re Gault, 387 U.S. 1 (1967).

108452 U.S. 18 (1981).

${ }^{100}$ Id. at 31-32. 
may lose his physical liberty through the proceedings. ${ }^{107}$ Because there was no possibility of a deprivation of physical liberty in Lassiter, the presumption operated against the petitioner and was not rebutted. ${ }^{108}$ In nonsupport contempt cases, however, physical liberty is always at stake; Lassiter's presumption is therefore inoperative. Because the result in Lassiter depended peculiarly on the presumption, the fact that the Court would go no farther than a case-by-case rule does not argue strongly that a similar result is compelled in the case of nonsupport contempt. ${ }^{109}$

In Gagnon v. Scarpelli ${ }^{110}$ the Court held that probationers do not have an unqualified right to appointed counsel in hearings to determine whether to revoke probation. The decision to appoint counsel was left to case-by-case decision by the hearing board.111

${ }^{107} \mathrm{Id}$. at 25-27. Establishing this presumption is one way to apply the results of past cases to the analysis of present ones. But the Court's reasoning is not beyond criticism. It might have been accidental that the Court had recognized a right per se to counsel only when the defendant stood to lose his liberty if he lost the litigation. If it was not accidental, then there must be some explanation for the observed regularity. Surely it is important to know the reasons, in order to see whether they apply to the present case. To adopt a presumption against the right to counsel on the basis of a blind checklist of past holdings comes close to begging the question against the petitioner.

108 The existence of the presumption makes it unclear whether the Court engaged in any balancing and thus makes the Court's Eldridge analysis obscure. The Court found that the interest at stake was very important (though presumably not as important as physical liberty), the state's interest in containing costs was moderate, the state had an interest in avoiding error because it desired the best possible placement of the children, and the risks of error were variable, depending on the complexity of the issues and the intellectual capacities of the parent. Id. at 31. In all, it appeared to find the case for appointing counsel persuasive, were it not for the presumption. Apparently because of the presumption, the Court strongly suggested that it could find a right to counsel in all parental rights hearings only if in all hearings the parent's interests were at their strongest, the State's interests were at their weakest, and the risks of error were at their peak. Id. Because not all cases are so extreme, the Court left the right to counsel to case-specific determinations. Id. at 31-32.

109 The nonsupport contempt defendant has a stronger claim to counsel than did the parent in Lassiter not only because of the liberty interest, but because the risk of error in contempt proceedings is inherently high. See supra notes 66-85 and accompanying text. The Court in Lassiter found the risk of error to be variable. 452 U.S. at 28-33.

Note also that in Lassiter the Court faced only two obvious choices regarding a rule for the appointment of counsel. It could have imposed a Gideon-type rule, see supra notes 2123 and accompanying text, and required the appointment of counsel for all indigent parents, or it could have imposed the case-by-case rule that it in fact adopted. In the nonsupport contempt case, there is a third option, the Argersinger-type rule, under which counsel must be appointed before any indigent defendant may be sentenced to jail, see supra notes 24-25 and accompanying text. The existence of this option can affect the Eldridge balance because it affects the cost to the state of a rule requiring the appointment of counsel. See supra text following note 98. Cf. infra notes 136-38 and accompanying text (discussing the effect of limited alternative rules on the Eldridge balance).

110411 U.S. 778 (1973).

11 The Court gave the following general guidelines:

counsel should be appointed in cases where the probationer requests it, 
In In re Gault, ${ }^{112}$ however, the Court determined that an indigent juvenile has an unqualified right to appointed counsel in any delinquency hearing that can result in his commitment to an institution in which his freedom will be curtailed.

Since the Court did not apply the Eldridge framework in either case, its position on the main points must be constructed. In Scarpelli the Court pointed out that one reason for denying the probationer appointed counsel in every case is that the probationer's right to liberty is diminished by his prior conviction. ${ }^{113}$ The juvenile in delinquency proceedings is differently situated; his liberty interest is undiminished. ${ }^{114}$ The nonsupport defendant is more like the juvenile in this respect: he comes before the court without the encumbrance of a suspended sentence of imprisonment $^{115}$ or the restrictions of probation, and his liberty interest, too, is undiminished. ${ }^{116}$

The probationer's risk of erroneous deprivation has two main sources: (1) the board might incorrectly find a violation of the conditions of probation; (2) having found a violation, the board might inappropriately revoke probation, either by not taking into account other information tending to justify or mitigate the offense or by

based on a timely and colorable claim (i) that he has not committed the alleged violaton of the conditions upon which he is at liberty; or (ii) that, even if the violation is a matter of public record or is uncontested, there are substantial reasons which justified or mitigated the violation and make revocation inappropriate, and that the reasons are complex or otherwise difficult to develop or present.

Id. at 790.

${ }^{112} 387$ U.S. 1 (1967). Gerald Gault was a 15-year-old boy accused of making lewd remarks to a neighbor on the telephone. He and his parents were called to a hearing before a juvenile court judge. Notice of the delinquency hearing was by personal note from a probation officer. The hearing was informal, but not unusually so. Neither Gerald nor his parents were represented by counsel. The neighbor was not present. Gerald was not allowed to call or cross-examine witnesses. He was not informed of his privilege against self-incrimination. No transcript or record was made. At the conclusion of the hearing, the judge committed Gerald as a juvenile delinquent to a state "industrial school" until he turned 21 . If he had been an adult, the offense would have been a misdemeanor punishable by a fine of $\$ 5$ to $\$ 50$ or imprisonment for not more than two months. No appeal was permitted under the law of the state, Arizona. Id. at 4-10.

21 Scarpelli, 411 U.S. at 789.

114 See id. at n.12. Gerald Gault himself was on juvenile probation for a previous offense, Gault, 387 U.S. at 4, but in neither Gault nor Scarpelli did the Court point to this fact as having diminished his rights in the delinquency proceeding.

${ }_{113}$ Probationers are not always under a suspended sentence. But a probationer not previously sentenced must be given a combined revocation and sentencing hearing in a court. Scarpelli, 411 U.S. at 781-82. This hearing is a stage in a criminal prosecution, and the probationer is entitled to his rights under the fifth, sixth, and eighth amendments as extended to the states, including the right to appointed counsel if he is indigent. Mempa v. Rhay, 389 U.S. 128 (1967).

116 See supra notes 56-65 and accompanying text. 
being unduly disposed to punish. ${ }^{117}$ The juvenile and the nonsupport defendant face similar risks. The Court in Scarpelli and in Gault viewed these risks as sufficiently high to require that the individual always be granted certain due process rights in connection with the hearing, including written notice and the right to confront and cross-examine witnesses. ${ }^{118}$ (It is assumed for the purposes of this comparison that the nonsupport defendant is guaranteed the same rights. ${ }^{119}$ ) But Scarpelli and Gault took very different views of the level of risk remaining after these due process rights have been granted. Scarpelli held that this residual risk varies with the skill of the probationer in presenting his case to the board. ${ }^{120}$ It is low when an articulate and intelligent probationer admits the violation and has no difficulty in making his explanations, and it is high when an unskilled and uneducated probationer disputes the charges or believes the offense justified or mitigated for reasons difficult for him to present. ${ }^{121}$ The Court in Gault found the residual risk to be high because children are too inexperienced and unskillful to represent their own interests or even to understand the proceedings. ${ }^{122}$ The indigent nonsupport defendant generally also faces a high risk of an erroneous confinement, even if he is granted other due process rights, because of the ease with which courts can misapply the civil contempt power. ${ }^{123}$

The effectiveness of counsel varies with the level of risk and the ability of the individual to cope with it by himself. The Court in Scarpelli thought that in most cases counsel would have little to contribute to probation revocation hearings ${ }^{124}$ and that the routine appointment of counsel would even be against the probationer's interests. ${ }^{125}$ The Court feared that if every probationer appeared with counsel, the state would provide its own, and the proceedings would lose their informal, nonadversary character, making the board more disposed to imprison than to continue probation. ${ }^{126}$ The Court acknowledged, however, that in some circumstances the effectiveness of the probationer's other due process rights will de-

117 See Scarpelli, 411 U.S. at 784. $33,57$.

118 Id. at 786 (quoting Morrissey v. Brewer, 408 U.S 471, 489 (1972)); Gault, 387 U.S. at

\footnotetext{
11 But see supra notes 7-11 and accompanying text.

120411 U.S. at 786-87.

121 See id. at 786-87, 790-91.

122387 U.S. at 38 n.65.

123 See supra notes $72-85$ and accompanying text.

124 See 411 U.S. at 787.

115 See id. at 787-88.

128 Id.
} 
pend on the use of skills that he does not have. When the probationer has difficulty in presenting his version of a disputed set of facts, must examine or cross-examine witnesses, or must dissect complex documentary evidence, counsel has a constructive role to play. ${ }^{127}$ In contrast, the Court in Gault reasoned that the juvenile, because of his immaturity, can never make satisfactory use of his due process rights or defend himself adequately without the assistance of counsel. ${ }^{128}$ The Court thus viewed counsel as not only highly effective but even indispensable in reducing the level of risk. ${ }^{129}$

The nonsupport defendant is similarly unable to protect himself adequately from the special risks of the contempt proceeding, not because he is immature, although occasionally he may be, but because adequate protection from unauthorized confinement requires an understanding of the law and skills in courtroom procedure and negotiation that the average defendant cannot be assumed to have. ${ }^{130}$ Furthermore, there is no reason to think that the increased use of counsel in nonsupport contempt hearings would have the counterproductive effects that concerned the Court in Scarpelli. The presence of counsel would not tend to change the concern of the court from rehabilitation to punishment. The primary concern of the court in civil contempt proceedings is the enforcement of its order. The proceeding is already adversary, ${ }^{131}$ and the risk of an unauthorized punitive disposition is at its highest when the proceedings are informal and counsel is not present. ${ }^{132}$ The likely effect of counsel in such circumstances is to reduce the risk that the court will resort to punitive sanctions by ensuring that the court's eye stays on coercion, with all its limitations, and does not stray to punishment. ${ }^{133}$

Costs weighed heavily in the Court's decision in Scarpelli ${ }^{\mathbf{3 4}}$ but were not considered at all in Gault. ${ }^{135}$ The only alternatives to a case-by-case rule in Scarpelli would have required the appointment of counsel in every case, a costly undertaking. ${ }^{136}$ But for non-

\footnotetext{
137 Id. at 786-87.

128 See 387 U.S. at 38 n.65.

129 See id. at 36-37.

130 See supra notes 85-93 and accompanying text.

1s1 See supra note 90.

1s2 See supra notes 86-89 and accompanying text.

133 See supra notes 91-93 and accompanying text.

134 See Scarpelli, 411 U.S. at 787-88.

135 See Gault, 387 U.S. at 34-42.

${ }^{138}$ A Gideon-type rule, by definition, requires appointment of counsel in every case. See supra notes 21-23 and accompanying text. An Argersinger-type rule would require appoint-
} 
support contempt proceedings, an Argersinger-type rule would require appointment of counsel only when the judge wished to preserve the option of confinement. ${ }^{137}$ The rule is an alternative to Scarpelli's case-by-case rule that could be significantly less costly than appointing counsel in every case. ${ }^{138}$

The analysis reveals that on the points that are most important for the choice between a case-by-case rule and a per se rule, the position of the nonsupport defendant more closely resembles that of the juvenile in Gault than that of the probationer in Scarpelli. The nonsupport defendant's liberty interest is essentially undiminished. The risk of an erroneous deprivation of liberty is of a sort that remains high in the usual case, even when other due process rights are granted. Representation by counsel is highly effective in reducing that risk, and no effects harmful to the interest of the defendant appear. Thus even if the costs were roughly the same, the pattern of Eldridge factors in the case of nonsupport contempt more strongly supports routine appointment of counsel than did the pattern of factors in the case of probation revocation. ${ }^{139}$

There are differences, however, between the position of the nonsupport defendant and that of the juvenile in Gault. The juvenile in delinquency proceedings faces possible confinement for the remainder of his minority, which could be several years. ${ }^{140}$ The nonsupport defendant is usually confined for a comparatively short period, generally less than a year. ${ }^{141}$ Thus the juvenile risks a greater loss of liberty. Furthermore, two constitutionally protected interests are commonly implicated in juvenile proceedings: the liberty of the child and the right of the parent to the child's custody. ${ }^{142}$ The pattern of Eldridge factors in juvenile delinquency

ment of counsel only when the probation board wished to preserve the option of confinement. See supra notes 25,96 and accompanying text. But when there is a prior sentence of imprisonment that has been suspended during the probation, the hearing board will always preserve the option of confinement, since the purpose of the hearing is to determine whether to revoke probation and reinstate the sentence.

${ }^{137}$ See supra notes 25,96 and accompanying text.

138 See supra text following note 98.

${ }^{139}$ It might be argued that the nonsupport defendant's risk is low in some courts and high in others, depending on the competence and disposition of the judge. This is doubtless true, see supra text following note 84 , but it lends no support to a case-by-case rule. Such a rule would be administered by the court, and no court can be expected to include in its deliberations the likelihood that it will misuse the contempt power. Courts from whom defendants are most in need of protection would be least inclined to give it.

140 See Gault, 387 U.S. at $36-37 \&$ n.60.

14 See, e.g., D. Chambers, supra note 1, at 187-88.

142 See Gault, 387 U.S. at 33-34. 
proceedings therefore more strongly supports a rule requiring appointment in every case than does the pattern in nonsupport contempt.

The comparisons show that the results of the Eldridge analysis for nonsupport contempt justify a per se rule for appointment of counsel, but not a rule so strong or so costly as to require appointing a lawyer for every indigent defendant. The Eldridge balance is fully satisfied by an Argersinger-type rule forbidding the confinement of any nonsupport defendant unless he is represented by counsel at his hearing or waives his right. ${ }^{143}$ This rule ensures that the defendant will be adequately protected from the risk of unauthorized confinement at a cost that, with effective administration, can be kept significantly below the cost of a rule requiring counsel in every case. ${ }^{144}$ Compliance with this rule by courts hearing cases of nonsupport contempt is thus a requirement of due process of law.

\section{Conclusion}

This comment has argued that in the absence of a knowing and intelligent waiver, no indigent defendant in civil contempt proceedings for nonpayment of child support may be imprisoned unless he was represented by counsel at his hearing. Courts thus must appoint counsel for such defendants if they wish to preserve the option of confinement. In states that have by statute effectively transformed their nonsupport contempt proceedings into criminal prosecutions, the authority for this rule is the sixth amendment's requirement of the assistance of counsel, as construed in Argersinger v. Hamlin. In states in which nonsupport contempt proceedings are beyond the reach of the sixth amendment, the authority for the rule is the due process clause of the fourteenth amendment. Though the proceedings may be civil, nonsupport defendants face a substantial risk of erroneous deprivation of their freedom. With counsel this risk is greatly reduced. Comparison with other right-to-counsel cases shows that this reduction in risk justifies the cost of administering the rule when the impor-

14 See supra notes $94-98$ and accompanying text.

144 See supra notes 96-98 and accompanying text. It is important that in the case of probation revocation there is no effective difference between an Argersinger-type and a Gideon-type rule. See supra note 136 and accompanying text. Thus the cost savings that can be achieved by adopting an Argersinger-type rule in preference to a Gideon-type rule for nonsupport contempt could not be achieved for probation revocation. For this additional reason the balance of Eldridge factors for probation revocation more strongly supports a case-by-case rule than the balance of factors for nonsupport contempt. 
tance of the interest at stake and the opportunities for cost containment are taken into account. 